\title{
APLIKASI XANTHAN GUM TERHADAP SIFAT KEHOMOGENAN DAN CITARASA KOPI PINOGU
}

\section{Xanthan gum application on homogeneous and flavor of Pinogu coffee}

\author{
Asniwati Zainuddin* \\ Program Studi Teknologi Hasil Pertanian, Fakultas Pertanian, Universitas Ichsan Gorontalo, Indonesia \\ Doi: 10.37195/jac.v2i1.99
}

\section{*KORESPONDENSI}

Telepon: +62-852-9961-3349

E-mail: asni.zainuddin@gmail.com

\section{JEJAK PENGIRIMAN}

Diterima: 11 Feb 2020

Revisi Akhir: 6 Mar 2020

Disetujui: 23 Mar 2020

\section{KEYWORDS}

Xanthan gum, Pinogu coffee, Homogeneous

\section{KATA KUNCI}

Xanthan gum, Kopi pinogu, Homogen

\begin{abstract}
Pinogu coffee is the plantation product that became the superior products of Bone Bolango Regency, Gorontalo Province. In general, the scent and flavor are the most important part of the final Coffee processing. This research aims to produce a proper formulation of a wide variety addition of the xanthan gum concentration on pinogu coffee. Completely Randomized Design method was conducted, that consisted of 5 treatment and 3 replications. A0 (without xanthan gum), A1 (250 ppm of xanthan gum), A2 (500 ppm of xanthan gum), A3 (750 ppm of xanthan gum), and A4 (1000 ppm of xanthan gum). The result showed that the proper and recommended formulation was the addition of 750 ppm of xanthan gum. It was because of the xanthan gum properties that served as a binding agent to keep the pinogu coffee homogeneous, thus all small particles dissolved in stirring and produced the distinctive scent and flavor of pinogu coffee.
\end{abstract}

Kopi pinogu merupakan produk hasil perkebunan yang menjadi produk unggulan di Kabupaten Bone Bolango, Provinsi Gorontalo. Secara umum, aroma dan citarasa merupakan bagian yang terpenting pada proses akhir dari pengolahan kopi. Tujuan penelitian ini adalah menghasilkan formulasi yang tepat pada berbagai konsentrasi penambahan xanthan gum pada kopi pinogu. Adapun metode penelitian yang dilakukan adalah menggunakan Rancangan Acak Lengkap (RAL) yang terdiri dari 5 perlakuan dengan 3 kali ulangan. A0 (tanpa xanthan gum), A1 (konsentrasi xanthan gum 250 ppm), A2 (konsentrasi xanthan gum 500 ppm), A3 (konsentrasi xanthan gum 750 ppm), dan A4 (konsentrasi xanthan gum 1000 ppm). Hasil penelitian menunjukkan formulasi yang tepat dan direkomendasikan pada penelitian ini adalah konsentrasi penambahan xanthan gum 750 ppm pada perlakuan A3. Hal ini disebabkan karena sifat dari xanthan gum yang berfungsi sebagai pengikat untuk menjaga produk kopi pinogu tetap homogen sehingga semua partikel kecil larut dalam pengadukan serta menghasilkan aroma dan citarasa yang khas dari kopi pinogu.

\section{PENDAHULUAN}

Peran tanaman kopi menjadi salah satu komoditi hasil perkebunan yang mendapatkan perhatian bagi masyarakat, universitas, pemerintah dan khususnya peneliti untuk dikembangkan. Penelitian ini mengacu pada
Rencana Induk Penelitian Universitas Ichsan Gorontalo dalam hal pemanfaatan dan pengembangan komoditi lokal serta pengaplikasiannya pada technopreneurship.

Kopi pinogu merupakan produk hasil perkebunan yang menjadi produk unggulan di 
Kabupaten Bone Bolango, Provinsi Gorontalo. Kopi pinogu berasal dari Kecamatan Pinogu yang merupakan sebuah kawasan yang sangat kaya dengan komoditas pertanian. Kopi pinogu merupakan produk olahan yang berasal dari kopi robusta dan kopi liberika. Kopi pinogu memiliki daya tarik dan keunggulan tersendiri dibandingkan dengan kopi dari daerah-daerah lain. Salah satu keunggulan kopi pinogu yaitu petani kopi pinogu tidak menggunakan pestisida, herbisida, maupun pupuk kimia lainnya.

Peningkatan produksi kopi di Gorontalo masih terhambat oleh rendahnya mutu biji kopi yang dihasilkan sehingga mempengaruhi pengembangan produk akhir dari produk kopi. Hal ini disebabkan, karena penanganan pascapanen yang kurang tepat. Selain itu spesifikasi alat atau mesin yang digunakan juga dapat mempengaruhi setiap tahapan pengolahan kopi pinogu, sehingga menghasilkan produk yang kurang homogen dan terdapat beberapa partikel yang tidak larut pada saat pengadukan kopi.

Penelitian terdahulu Zainuddin (2014), menyatakan bahwa penggunaan xanthan gum pada susu kedelai sebagai emulsifier yang berfungsi untuk menyatukan atau mengikat kandungan pati dan lemak pada susu kedelai kemasan. Pada konsentrasi yang lebih tinggi xanthan gum digunakan sebagai "suspending agent" yang sangat baik digunakan untuk menghilangkan pulp dan bahan-bahan lain yang dapat membuat keruh dalam beberapa produk minuman. Xanthan gum juga dipakai sebagai penstabil untuk mengemulsi minyak flavor (flavour oil emulsion) dalam beberapa jenis minuman khusus. Kisaran konsentrasi xanthan gum yang dapat digunakan dalam minuman antara $0,001 \%-0,15 \%$ karena kestabilan terhadap perlakuan panas yang khas dengan menggabungkan sifat penstabil emulsi dan suspending agent, maka xanthan gum sesungguhnya dapat digunakan dalam sistem pengalengan pangan.

Mikroorganisme yang paling banyak digunakan pada pembuatan xanthan gum adalah Xanthomonas campestris, karena xanthan gum yang diproduksi dari Xanthomonas campestris, telah menunjukkan karakteristik produk komersialnya (García-Ochoa, Santos, Casas, \& Gómez, 2000). Kebanyakan makanan yang mengandung xanthan gum, biasanya menggunakan takaran sebanyak 0,5\% dan dapat digunakan dalam jumlah yang lebih rendah. Semakin banyak jumlah xanthan gum yang ditambahkan, maka kestabilannya semakin tidak teratur. Penambahan xanthan gum dalam produk pangan berfungsi sebagai pencegah terjadinya pemisahan minyak dengan menstabilkan emulsi, membantu memperkuat partikel padat, membantu menciptakan tekstur yang lembut, pengikat, dan pengembang bebas gluten. Secara umum aroma dan rasa merupakan unsur yang sangat penting pada proses akhir dari produk kopi.

Salah satu bahan penstabil yang digunakan untuk mencegah pengendapan pada seduhan kopi pinogu adalah xanthan gum, yang viskositasnya sangat stabil pada berbagai $\mathrm{pH}$ dan temperatur. Dari uraian latar belakang, peneliti tertarik melakukan penelitian dengan tujuan menghasilkan formulasi yang tepat pada berbagai konsentrasi penambahan xanthan gum pada kopi pinogu.

\section{BAHAN DAN METODE}

\section{Bahan}

Bahan yang digunakan pada penelitian ini adalah aquades, air, xanthan gum (diproduksi oleh Fufeng, China), dan biji kopi robusta dari Desa Dataran Hijau, Kecamatan Pinogu, Kabupaten Bone Bolango.

\section{Desain Penelitian}

Penelitian ini menggunakan rancangan acak lengkap (RAL). Terdiri dari 5 perlakuan model sistematis dengan 3 kali ulangan analisis sidik ragam, bila terdapat pengaruh pada perlakuan, maka diuji menggunakan Duncan.

Perlakuan yang dilakukan pada penelitian ini adalah:

$\mathrm{A} 0=$ tanpa $x$ anthan gum

$\mathrm{A} 1=$ konsentrasi $x$ anthan gum $250 \mathrm{ppm}$

$\mathrm{A} 2=$ konsentrasi $x$ anthan gum $500 \mathrm{ppm}$

$\mathrm{A} 3=$ konsentrasi $x$ anthan gum $750 \mathrm{ppm}$

A4 = konsentrasi $x a n t h a n$ gum 1000 ppm

\section{Pengolahan Bubuk Kopi Pinogu}

Pengolahan bubuk kopi pinogu dilakukan dengan cara, ditimbang buah kopi pinogu sebanyak $4 \mathrm{~kg}$, kemudian disortasi dan dilepaskan kulit buahnya dan dibersihkan. Setelah selesai pelepasan kulit buah, selanjutnya difermentasi dengan cara 
fermentasi semi basah, yaitu biji kopi dimasukkan ke dalam plastik bening, diikat dan kemudian dimasukkan ke dalam karung plastik, selama 24 jam dengan menggunakan suhu ruang dan dilanjutkan pencucian, biji kopi dimasukkan ke dalam ember plastik ditambahkan air diaduk-aduk dengan tangan untuk melepaskan sisa lendir yang masih melekat. Setelah pencucian berakhir, dikeringkan dalam oven pada suhu $65-100^{\circ} \mathrm{C}$. (Najiyati \& Danarti, 2004). Dilanjutkan penyangraian selama 10 menit. Setelah proses penyangraian selesai, biji kopi harus didinginkan. Selama pendinginan biji kopi diaduk secara manual agar proses pendinginan lebih cepat dan merata. Kemudian dilakukan penggilingan dan pengayakan dengan menggunakan ayakan 100 mesh.

\section{Penambahan Konsentrasi Xanthan Gum pada Bubuk Kopi Pinogu}

Bubuk kopi pinogu yang dihasilkan dari proses fermentasi dilanjutkan dengan olahan bubuk kopi dengan penambahan konsentrasi xanthan gum. Disiapkan bubuk kopi pinogu sebanyak 1000 gram yang telah difermentasi kemudian dilakukan penambahan xanthan gum untuk memberikan citarasa yang khas dan mengurangi endapan/buih pada bubuk kopi pinogu. Selanjutnya bubuk kopi dan xanthan gum dihomogenkan kemudian dilakukan analisis meliputi kadar air, stabilitas seduhan dan uji organoleptik.

\section{Metode Analisis}

Penentuan Kadar Air (AOAC, 1984). Kadar air ditentukan dengan cara pengeringan di dalam oven. Bahan ditimbang sebanyak $\pm 3 \mathrm{~g}$ dimasukkan dalam wadah yang telah diketahui beratnya, kemudian dimasukan ke dalam oven yang bersuhu $105^{\circ} \mathrm{C}$ selama 4 jam. Kemudian sampel didinginkan dalam desikator selama 10 menit dan ditimbang. Oven dipanaskan lagi selama 1 jam, didinginkan dalam desikator dan ditimbang. Perlakuan ini diulang sampai tercapai berat konstan (selisih penimbangan berturut-turut tidak lebih dari 0,02 g).

\%Kadar air $=\frac{\text { Berat awal }(\mathrm{g})-\text { Berat akhir }(\mathrm{g})}{\text { Berat awal }(\mathrm{g})} \times 100 \%$

Stabilitas Seduhan. Pengamatan stabilitas seduhan mulai dilakukan setelah minuman diseduh. Pengamatan dilakukan secara visual dengan menggunakan bantuan alat stopwatch, kemudian dicatat waktu hingga terbentuk endapan dan diukur tinggi endapannya. Pengukuran stabilitas seduhan dapat dihitung dengan rumus:

$$
\text { Stabilitas seduhan }=\frac{A-B}{A} \times 100 \%
$$

dimana:

$\mathrm{A}=$ Total volume

$\mathrm{B}=$ Total volume endapan

Uji Organoleptik. Uji organoleptik yang dilakukan meliputi, aroma dan rasa dari kopi pinogu dengan penambahan konsentrasi xanthan gum. Metode pengujian yang dilakukan metode hedonik (uji kesukaan). Sampel disajikan secara acak pada 30 orang panelis masing-masing panelis disediakan 15 jenis seduhan kopi yang diberi kode yang berbeda. Hasilnya dinyatakan dalam skala hedonik yang digunakan yaitu:

$$
\begin{array}{ll}
\text { 1= Sangat tidak suka } & \begin{array}{l}
4=\text { Suka } \\
\text { 2= Tidak suka }
\end{array} \\
\text { 3= Agak suka } &
\end{array}
$$

\section{HASIL DAN PEMBAHASAN}

\section{Kadar Air}

Hasil analisa sidik ragam dapat dilihat pada (Tabel 1) menunjukkan pengaruh yang nyata pada taraf $5 \%$ dan pada uji lanjut duncannya menunjukkan huruf yang berbeda pada setiap perlakuan, hal ini dinyatakan berbeda nyata secara statistik. Kadar air terendah pada penelitian ini adalah $1,98 \%$ pada perlakuan A1 dengan penambahan xanthan gum 250 ppm, hal ini disebabkan oleh sifat xanthan gum yang mampu memfasilitasi ketersediaan gugus hidrofilik dalam mengikat air (Julianti, Rusmarilin, Ridwansyah, \& Yusraini, 2017). Sifat dari xanthan gum yang mampu mengikat air dengan takaran 250 ppm pada kopi pinogu dapat mempengaruhi daya simpannya.

\section{Stabilitas Seduhan}

Kebanyakan makanan xanthan yang digunakan sebesar 0,5\% dan dapat digunakan dalam konsentrasi yang lebih rendah. Semakin tinggi xanthan gum yang digunakan, maka kestabilannya akan semakin tidak 
Tabel 1. Data hasil pengujian penambahan xanthan gum pada kopi pinogu

\begin{tabular}{ccccc}
\hline \multirow{2}{*}{ Perlakuan } & \multicolumn{4}{c}{ Parameter Pengamatan } \\
\cline { 2 - 5 } & Kadar Air (\%) & Stabilitas Seduhan (\%) & Aroma (skor) & Rasa (skor) \\
\hline A0 & $2,29 \mathrm{a}$ & $85,62 \mathrm{ab}$ & $3,43 \mathrm{ac}$ & $3,64 \mathrm{a}$ \\
A1 & $1,98 \mathrm{a}$ & $87,17 \mathrm{a}$ & $3,52 \mathrm{ab}$ & $3,42 \mathrm{a}$ \\
A2 & $2,65 \mathrm{ab}$ & $87,74 \mathrm{a}$ & $3,45 \mathrm{ac}$ & $3,81 \mathrm{ac}$ \\
A3 & $3,47 \mathrm{~b}$ & $81,12 \mathrm{c}$ & $3,80 \mathrm{~b}$ & $3,43 \mathrm{ad}$ \\
A4 & $5,19 \mathrm{c}$ & $84,55 \mathrm{ab}$ & $3,16 \mathrm{c}$ & $3,33 \mathrm{bd}$ \\
\hline
\end{tabular}

Keterangan: Notasi yang berbeda menunjukkan adanya perbedaan yang nyata pada taraf signifikasi $a$ 0,05

teratur. Hal ini disebabkan karena xanthan gum meningkatkan keterikatan granula pati tergelatinisasi dan memerangkapnya dalam sistem koloid sehingga mencegah granula terlarut ke medium (Mandala \& Bayas, 2004). Hasil pengamatan menunjukkan hasil perhitungan persentase stabilitas seduhan berdasarkan pada perbandingan total volume dan total endapan kopi pinogu. Stabilitas seduhan terbaik pada penelitian ini adalah pada perlakuan A2 dengan penambahan xanthan gum 500 ppm. Kopi pinogu dengan stabilitas terbaik memiliki laju pengendapan terendah. Hal ini diduga bahwa xanthan gum merupakan biopolimer yang hidrofilik dan dapat larut. Sifat dari xanthan gum yang ditambahkan pada kopi pinogu yaitu kelarutan dan kestabilannya sangat baik pada kondisi asam dan basa sehingga larutan kopi bersifat homogen. Hal ini dibuktikan dengan pendapat Van De Velde dan De Ruiter (2005) dalam Wijaya, Kardono dan Halim (2015), bahwa penurunan selisih berat jenis dan peningkatan viskositas dapat mengurangi laju pengendapan suspensi.

\section{Aroma}

Sivetz (1972) menyatakan bahwa pembentukan aroma yang khas pada kopi dipengaruhi oleh kafeol dan komponen senyawa-senyawa pembentuk aroma kopi lainnya. Respon panelis terhadap aroma kopi pinogu yang dihasilkan (Tabel 1) menunjukkan skor tertinggi terdapat pada perlakuan $\mathrm{A} 3$ yaitu 3,8 (suka), sedangkan skor terendah terdapat pada perlakuan A4 yaitu 3,16 (agak suka). Formulasi yang direkomendasikan pada penilaian aroma adalah konsentrasi penambahan xanthan gum 750 ppm pada perlakuan A3. Aroma kopi dapat dirasakan ketika kopi diseduh. Pada saat bersamaan, senyawa volatil yang terdapat pada kopi akan menguap ke atas memasuki saluran penciuman. Menurut Bylaite, Adler-Nissen, dan Meyer (2005), penambahan hidrokoloid akan menurunkan penerimaan terhadap atribut aroma. Penurunan tingkat penerimaan atribut aroma ini, mungkin merupakan hasil dari dua mekanisme utama yaitu penurunan tingkat difusi di media karena solusi peningkatan viskositas dan adanya interaksi komponen flavor dan unsur pokok dari matrik hidrokoloid.

\section{Rasa}

Respon panelis terhadap rasa pada kopi pinogu dengan penambahan $x a n t h a n$ gum yang dihasilkan (Tabel 1) menunjukkan skor tertinggi terdapat pada perlakuan A2 dengan skor 3,81 yaitu suka, sedangkan skor terendah terdapat pada perlakuan A4 dengan skor 3,33 yaitu agak suka. Formulasi yang direkomendasikan pada penilaian rasa adalah konsentrasi penambahan xanthan gum 500 ppm pada perlakuan A2.

Terbentuknya rasa pada bubuk kopi sesungguhnya terjadi pada saat suhu biji kopi antara $140{ }^{\circ} \mathrm{C}-160{ }^{\circ} \mathrm{C}$ pada proses penyangraian yang dapat mencapai suhu $230^{\circ} \mathrm{C}$. Beberapa komponen pembentuk flavor rasa merupakan senyawa-senyawa volatil yang bersifat larut dalam air yang merupakan pembentuk rasa pahit. Proses fermentasi juga menumbuhkan citarasa, aroma, dan warna yang baik karena selama fermentasi terjadi penguraian senyawa polifenol, protein, dan gula oleh enzim yang menghasilkan senyawa aroma, perbaikan rasa (Widyotomo, Mulato, \& Handaka, 2004).

Rasa yang terdapat pada bubuk kopi dipengaruhi oleh beberapa faktor. Faktor tersebut diantaranya adalah bahan baku yaitu 
jenis tanaman kopi atau biji kopi yang digunakan, tingkat kemasakan biji kopi pada saat pemanenan, cara pengolahan, cara serta lama penyimpanan. Selain itu rasa dari kopi juga dipengaruhi dari cara penggorengannya (roasting), jika cara penggorengan menggunakan cara tertutup maka rasa dari kopi akan semakin kuat dikarenakan komponen-komponen volatil pada biji kopi tidak banyak menguap, sedangkan jika menggunakan cara penggorengan dengan terbuka maka cita rasa dan aroma dari kopi akan semakin berkurang dikarenakan komponen dari biji kopi banyak yang menguap ke udara.

\section{KESIMPULAN}

Dari hasil penelitian diperoleh kesimpulan yaitu formulasi yang tepat dan direkomendasikan pada penelitian ini adalah konsentrasi penambahan xanthan gum 500 ppm pada perlakuan A2.

\section{PENGHARGAAN}

Ucapan terima kasih kepada ketua Lembaga Penelitian Universitas Ichsan Gorontalo yang telah memberikan bantuan dana serta pihak-pihak yang telah membantu penelitian ini.

\section{DAFTAR PUSTAKA}

AOAC. (1984). Official method of Analysis of The Association of Official Analytical chemistry (14th ed.). Virginia: AOAC. Inc.

Bylaite, E., Adler-Nissen, J., \& Meyer, A. S. (2005). Effect of xanthan on flavor release from thickened viscous food model systems. J. Agric. Food Chem. 53(9), 3577-3583.

García-Ochoa, F., Santos, V. E., Casas, J. A., \& Gómez, E. (2000). Xanthan gum: production, recovery, and properties. Biotechnol Adv., 18(7), 549-579.

Julianti, E., Rusmarilin, H., Ridwansyah, \& Yusraini, E. (2017). Functional and rheological properties of composite flour from sweet potato, maize, soybean and xanthan gum. Journal of the Saudi Society of Agricultural Sciences, 16(2), 171-177.

Mandala, I. G. \& Bayas, E. (2004). Xanthan effect on swelling solubility and viscosity of wheat starch dispersions. Food Hydrocolloids, 18(2), 191-201.
Najiyati, S. \& Danarti. (2004). Kopi: Budidaya dan Penanganan Pascapanen. Jakarta: PT. Penebar Swadaya.

Sivetz, M. (1972). How acidity affects coffee flavour. Food Technology, 26(5), 70-77.

Widyotomo, S. Mulato, S., \& Handaka. (2004). Mengenal lebih dalam teknologi pengolahan biji kakao. Warta Penelitian dan Pengembangan Pertanian Indonesia, 26(2), 56.

Wijaya, C., Kardono, L. B. S., \& Halim, J. M. (2015). Peningkatan akseptabilitas susu kecipir (Psophocarpus tetragonolobus (L.) DC.) dengan adisi bahan penstabil dan jus jahe. Jurnal Aplikasi Teknologi Pangan 4(4), 112-123.

Zainuddin, A. 2014. Analisis dan aplikasi gum xanthan terhadap produk susu kedelai. Jurnal Agrokompleks, 3(7), 2-9. 